\title{
POLLUTION MIGRATES TO THE WEST Wuqiriletu
}

\section{I}

N MONGOLIAN, Tengger means both 'heaven' and 'huge'. Most of China's Tengger Desert 腾格里沙漠 falls in Inner Mongolia, but it also extends into the northwestern provinces of Ningxia and Gansu. At 36.7 thousand square kilometres, it is China's fourth largest desert. It is dotted with hundreds of freshwater lakes surrounded by fertile areas of grass and vegetation that have sustained nomadic herders and their animals for thousands of years.

However, beginning in the late 1990s, the local governments of Inner Mongolia and Ningxia have been building industrial parks in the desert, including many chemical manufacturing plants. These enterprises discharge untreated wastewater into the desert, polluting groundwater resources and destroying desert ecosystems, threat- ening the survival of local herders, their families, and their animals.

The local people's complaints have fallen on deaf ears. In 2011, after one herder, Urhaan, failed to get any meaningful response from local government, he erected a board by a road near to his home on which he wrote: 'Dear leaders, the pollution is serious!' 各位领导, 污染严重.

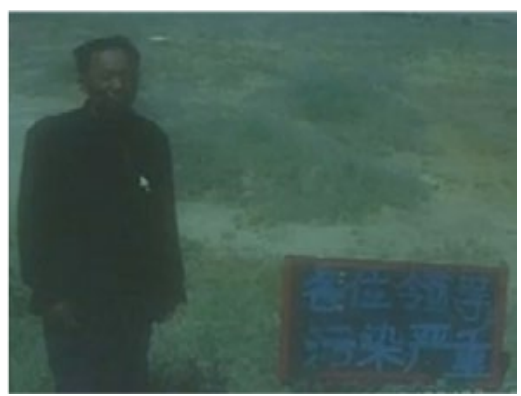

'Dear leaders, the pollution is serious' Photo: blog.163.com 

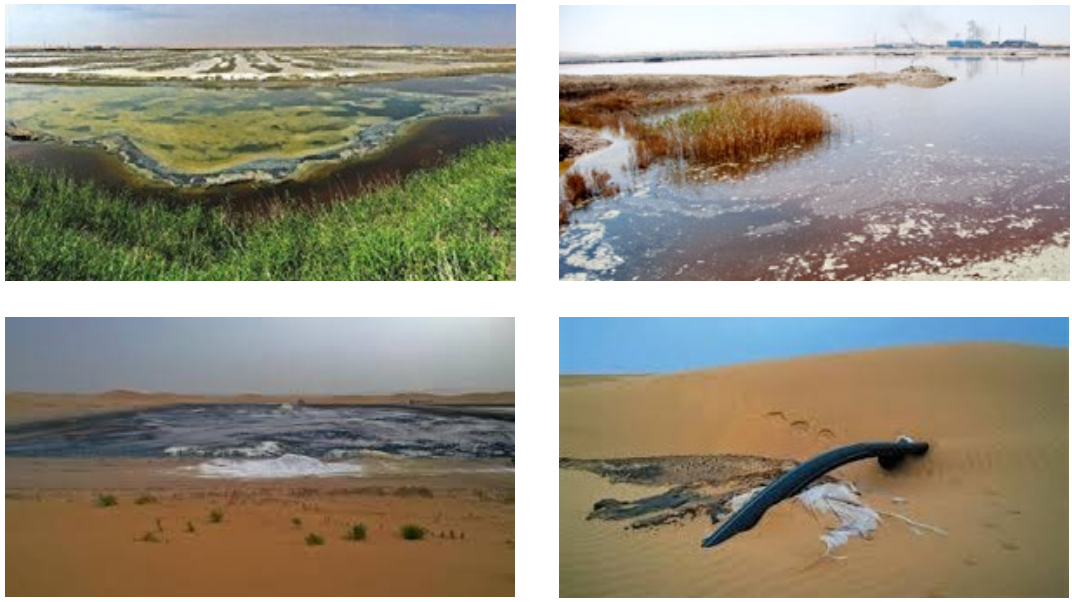

Pollution of the Tengger Desert

Photo: [Clockwise from top left] People's Daily, Bert van Dijk/Flickr; wzaobao.com; and chinadialogue.net

In 2013, another, younger Mongolian herder named Batuu addressed an informal seminar in Beijing on groundwater pollution that was organised by journalists, scholars, and environmental activists. He noted that the number of chemical factories in the Tengger had increased within a decade from a few to dozens. He described how these enterprises discharge wastewater directly into the desert, burying any residue after the water evaporates or seeps into the sand. After a few windy days, the polluted area 'disappears' completely. Water is already sparse in the desert; pollution of the under- ground water threatens the survival of both animals and people.

Journalists were aware of the issue. In 2011, the Times Weekly 时代 周报 reported on it in detail. Two years later, on the UN-sponsored World Water Day (22 March), China Central Television (CCTV) broadcast a report they titled 'abscess in the desert'.

Yet nothing changed until September 2014, when two influential news media organizations, The Beijing News 新京报 and the Southern Weekend 南方周末 fiercely criticised the local authorities for their inaction. Soon after that, the central leadership stepped 
in. Xi Jinping and other central leaders ordered the party committees and government of the Inner Mongolian autonomous region to halt the pollution of the Tengger Desert.

The Supreme People's Procuratorate of China, meanwhile, investigated criminal breaches of environmental law, listing four 'key' cases from Inner Mongolia, Ningxia, and Gansu. On 7 May 2015, it fined the Ming Sheng Dyeing Company 明盛染化公司 five million yuan, additionally fining Lian Xinzhong 廉兴中, the company's responsible executive, fifty thousand yuan and giving him a suspended sentence of eighteen months. This was named one of the 'hottest' ten cases of the year by Sina.com's news centre. Comments on the Chinese Internet noted the absurdity of the authorities having to wait for an instruction from the highest leadership before acting.

Worse, more and more polluting industries are relocating to remote parts of western China with the apparent intention of avoiding the increasingly stringent anti-pollution measures in economically developed regions of the east-a phenomenon dubbed Pollution Migrates to the West 污染西迁. Indeed, on 17 November 2015, official media announced that between 2013-2015, Beijing had successfully eliminated 1,006 of its polluting enterprises. The report did not say where these enterprises had gone. A year earlier, when a person in Inner Mongolia posted his fears that they were simply moving to Inner Mongolia, he was detained by local police for ten days and fined 500 yuan for 'spreading rumours'.

In May 2015, when I was in Inner Mongolia, I heard many people voice their fears that the number of power plants being built there meant 'you will never see the sun again in the grasslands'. I heard some say that 'Inner Mongolian people are like candles, burning themselves to provide illumination for others', referring to the fact

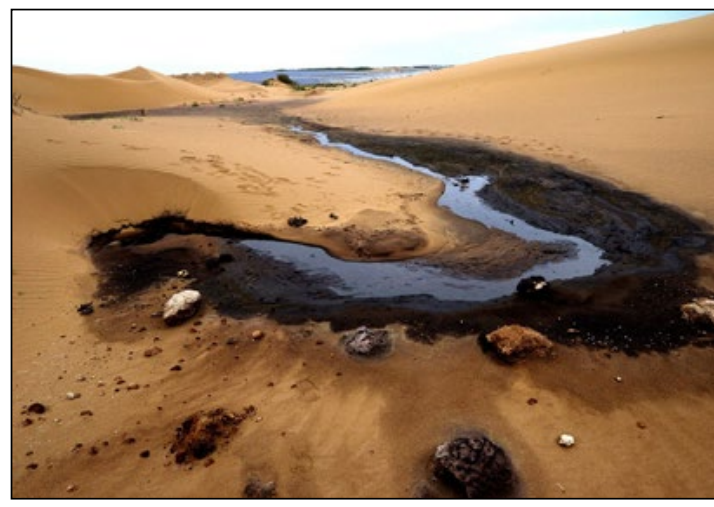

7 May 2015: the Ming Sheng Dyeing Company was fined five million yuan for breaching the environmental law

Photo: Xinhua 


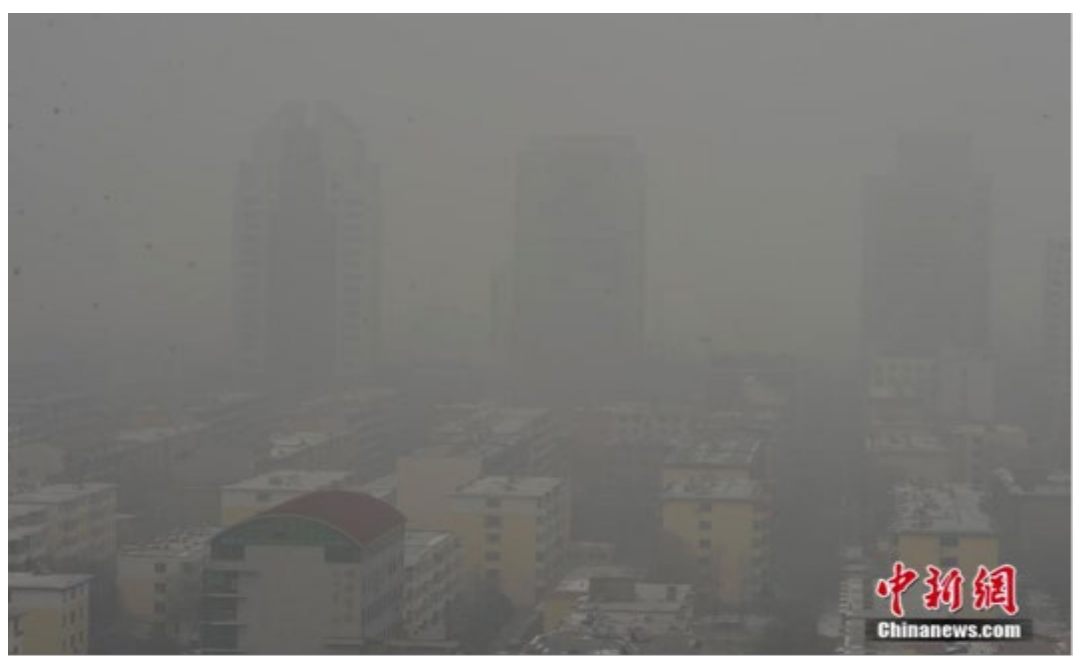

Heavy smog in Hohhot

Photo: chinanews.com

that coal-fired electricity is produced in Inner Mongolia for use in Beijing and elsewhere.

These rumours, if that's what they are, are not totally groundless. As early as 2013, the National Business Daily 每日经济新闻 reported that while the Air Pollution Prevention Action Plan restricted the building of new coal-fired power projects in eastern regions such as Jing-Jin-Ji (See Chapter 5 'The City that Ate ChinaRestructuing and Reviving Beijing,

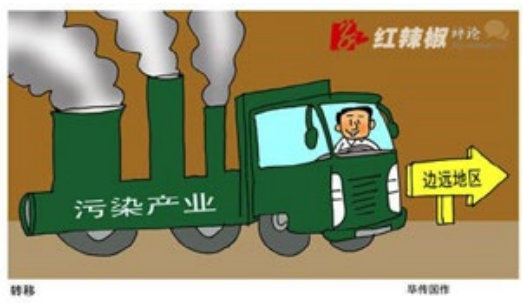

Pollution Migrates to the West Source: news.163.com pp.178-201), they were springing up in western provinces including Shanxi, Shaanxi, Inner Mongolia, and Ningxia. According to China Energy News 中 国能源报, 120 new plants have been approved (another source says 155), of which forty-eight are to be located in western China and seventeen of these in Inner Mongolia.

Already, Asia's largest coal-fired power plant is located close to Hohhot, the capital city of Inner Mongolia, which is already plagued with heavy smog in winter. Built in 1995, its main task according to Wang Dongsheng 王东升, the party secretary, in 2015, is to 'ensure power supply to Beijing without polluting Inner Mongolia'. If you substitute 'western China' for 'Inner Mongolia', that is the challenge in a nutshell. 
This text is taken from China Story Yearbook 2015: Pollution, edited by Gloria Davies, Jeremy Goldkorn and Luigi Tomba, published 2016 by ANU Press, The Australian National University, Canberra, Australia. 